\title{
On the Functional Significance of Confucian Music Education
}

\author{
Yong-qiang LEI \\ School of Marxism, Henan University of Science \& Technology, Luoyang, Henan, China
}

Keywords: Functional significance, Confucius, Music education.

\begin{abstract}
With the spreading of the consumerist culture, the contemporary Chinese musicology seems to focus on the performance skills of music, without emphasis on the moral connotation of music. Confucius attached great importance to the educational function, the communicative function and the political function in music teaching, and regarded music as the accomplishments of a moral personality. Creating the Ren (Benevolence) system and displaying the subjectivity of human being, Confucius reconstructed humanism of the traditional music, making music education and people's life style inseparable. Currently, it is very meaningful to make research into Confucius's music education and revitalize traditional music education.
\end{abstract}

\section{Introduction}

Music education is an important part of Chinese propriety and music culture. Basing on the strong sense of historical mission, Confucius summarized the theory of ancient music, and had deep attainments in music. He made great contributions to the preservation and dissemination of ancient Chinese music culture. In the classics as "The Analects of Confucius" and "Confucius Aristocratic family in Shi Ji", there were many stories recording that Confucius had communicated with those famous masterful palace musicians in Lu state and Qi state, and those folk musicians as Shi Zhi, Shi Xiang-zi and Shi Mian. In the process of communication, Confucius learned music from them. Confucius also deeply involved with civil and collected folk songs, and reorganized the Book of Songs. And then he dubbed in background music for those 305 poems in the Book of Songs, and made them accord with the tone of those classic pieces as Shao music, Wu music, Ya music and Song music. Confucius attached great importance to music teaching, believing music education could make a person perfect.

Confucius reconstructed humanism of the traditional music. He created the Ren (Benevolence) system and displayed the subjectivity of human being, which made music education and people's life style inseparable. All cultural ideas of education must be implemented by a certain kind of living customs, ceremonies and ritual systems to prove its effectiveness. Confucius advocated music education and believed that the music is outside display of the human's inner emotion. Just as what had said in the Fang Ji of the Book of Rites, music can control one's emotion and make one graceful, so he integrated traditional Ya (gagaku) music in people's lives, and civilized people imperceptibly by singing the Ya songs together. He took music as the main content of his teaching and life, even when he was trapped in the state of Chen and Cai, Before his death, he sang the songs as before. It means that the music had been deeply integrated into his daily life, and became indispensable. 
Confucius advocated music education, insisting "deny self and return to propriety". On the one hand, the music can correct one's heart and cultivate one's moral character. On the other hand, music can be used to match the ritual rules, and to educate the world, and ultimately achieve the functional significance of his ideal music education.

\section{The Educational Function of the Ancient Ya Music in Cultivating Moral Characters}

In the Spring and Autumn period, music education was the integration of moral education, language education, physical education and art education, which was the comprehensive quality education. Its goal was to cultivate one's moral character by music education, and finally ended in perfection. But the ethics starts from the heart. So the first prerequisite of Confucian music education was to correct man's heart, namely, playing Ya music to correct man's heart. It stressed that when listening the music full of vitality, the moral subjects would constantly made self-examination, and reflected oneself again and again. Then he could recognize the source of the utmost goodness of the human nature in the harmonious music. And thus to accumulate personal virtue in one's daily life, to achieve moral self-perfection, just as what Confucius said it was from the Music that the accomplishments of a moral personality was received. The chapter of music in Shi Ji records that when a wise king in ancient time played music, his purpose was not to amuse himself, but to educate and rule. All the right education starts from music education. When the music is correct, and the behavior follows. So the music can inspire man's blood, motivate the spirit, and make one's heart correct and be in harmonious state, which can clearly prove the function and significance in correcting the music education by Ya music. A wise king can depend on Ya music to purify one's soul and correct the education. So Confucius emphasized the rectification of names and advocated Ya music. Ya in ancient China means rectification, so the correction of music has become the proper meaning of the rectification of names according to the ancient patriarchal clan system.

Meanwhile, Confucius regarded music education can cultivate a man's morality and promote to the realm of Ren (Benevolence). When children are singing and dancing under a veil of religious mystery, the Respecting-God-and-Abiding-Ancients-Thought will created in their mind and their souls gradually reach to the ethics state. [1] The music in Confucius era was composed of three basic elements as "poetry", "song" and "dance". The Confucian Zhang Zai in Song dynasty said that the heart could lead the human nature, which was in line with Confucius. This heart here is the one that exists in individual and is inseparable from morality. The Ya music education emphasize on moral cultivation and can go deep into the human heart. And if a king advances the upright Ya music and sets aside the crooked shameless music, then the credit will be self-evident. Loving the Ya music and hating the shameless music is a common virtue to man. When playing the Ya music, the human's upright virtue including honesty will be shown instantly. The educational function of the ancient Ya music is to encourage people to be positive, and make the crooked upright, because it can wash away the scum of the heart as well.

Since the human's benevolent heart cannot be lost, we must always self-exam our hearts. Our ancestors believed that "the music was the flowers on the moral trees" and that the music full of virtue could influence man's inner heart. So the courageous and energetic music can arouse people's fortitude; integrity, dignity and devotional music can fill people with a sense of solemnity; soft and harmonious music can stimulate feelings of love and kindness. The Ya music just like a clear mountain stream, it can rinse out the dirt of the heart, "it can purify one's 
spirit of evil thoughts, and it can self-cultivate and make one return to innocence". [2] Nevertheless, "if the music full of evil ideas become popular, the man's heart will be greedy". (Chapter of Music in Shi Ji) So the gentlemen would refuse to listen to such kind of evil music. Furthermore, the Ya music is building on man's virtuous nature. When one was immersed in it for a long time, the sound full of virtue would be kept in the mind which can change temperament and make a person to be civilized, elegant and polite in manner. (Chapter of Music in Shi Ji). Therefore, music has the efficacy of mind training. In the Spring and Autumn period, the music is one of the necessary ways to cultivate the morality for the children of the ruling class. In ancient times, the method of selecting talents is to exam one's music learning firstly, by which to see a person's character. According to the ancients logic, if one understands the music, he will be able to understand the principles of human nature, to distinguish or identify species or groups, to get through the life and the death in the real world. And this was regarded as the hub or the standard for a qualified scholar-official in ancient China. Chapter Xian Wen of Confucian Analects records that Tsze-lû asked how to educate successfully. Confucius answered, "Suppose a man with the knowledge of Tsang Wû-chung, the freedom from covetousness of Kung-ch'o, the bravery of Chwang Pien, and the varied talents of Zan Ch'iû, then educate them by propriety and music, they might become complete ones." Wisdom, honesty, courage, art are four basic elements. One should have morality and capacity firstly. Then his wisdom is enlightened, his morality, courage and arts are developed or cultivated. Moreover, he is educated by propriety and music, then he will become a complete person." A person's ability can be revealed by the work engaged, when he has the intelligence to study, few desires in mind, courage to face the world, and artistic skill to communicate, then he keeps self-discipline by propriety, and communicates with others by harmonious music, step by step, he makes progress and becomes a complete person. There also is recorded in chapter Xian Jin of Confucian Analects, Confucius said, "Why Tsze-lû played the harp in my house?" The classmates began to disrespect Tsze-lû. Confucius then made corrections, "Tsze-lû has ascended to the hall, though he has not yet entered into the inner chamber." Tsze-lû's character is strong and brave, when he played the harp, a strong, brave spirit lingered in the air. Music likes the person, only the music cannot be forged. Here, Confucius used the metaphor of passing through the hall into the inner chamber to describe Tsze-lû's depth of knowledge. Because the standard of music is the golden mean, but Tsze-lû was just fierce, he had not understood the connotation of the harp playing, so Confucius was kindly criticizing Tsze-lû and hope him to cultivate virtue in playing the harp.'Music and morality are interlinked." (Chapter of Music in Li Ji) Music is the product of human spiritual activities; its sound and beautiful melody can produce emotional fluctuations on the basis of physiological stimulation, and form a variety of different psychological feelings, so it can provide people with rich music aesthetic information, and influence the personality, temperament, and interest of people imperceptibly. It can also help people enhance personality and form a healthy psychological imperceptibly, and finally to perfect the personality.

\section{Making People Keep Friendly with Each Other by the Communicative Function of the Music}

Confucius paid specialattention to the communicative function of music. The chapter of Ji Shi in Confucian Analects records that Confucius once said, "There are three things in which men 
can find enjoyment, the third is to find enjoyment in having many worthy friends." He regarded the number of likeminded friends as one of the criteria for judging the success of one's life, and considered the music as a way of communication. Confucius once told his son Bo-yü the importance of music learning and alert him. He said: "Have you studied the songs as Zhou-nan and Shâo-nan? The man who has not studied Zhou-nan and Shâo-nan is just like one who stands with his face right against a wall."(Chapter of Yang Huo in Confucian Analects) Zhou-nan and Shâo-nan are the first two songs of the Book of Odes. Mr. Qian Mu carried out textual research and pointed out that, in the Spring and Autumn period, Zhou-nan and Shâo-nan songs are used for country music, people sung them together. If a person couldn't sing them, he would be very lonely and isolated, although he is in the crowd, but looks like facing the wall alone. [3] Those music which can express the inner beauty of morality is good to life, and making friends through the music is the realization of the musical value. The Chapter of Yan Yuan in Confucian Analects records a paragraph of words of Zeng Sheng," A superior man always uses the culture to meet friends, and the friendship can help the cultivation of virtue." It truly reflects Confucius's ideas. Culture means ritual, music and articles, gentlemen make friends through it. Since they are friends, then they can discuss the Tao together, which can enhance benevolence. Reaching the state of benevolence is inseparable from the friends' mutual assistance. Music is a kind of culture, so man can use the music to meet friends, because the music is an ideal channel to communicate for its openness. The rhythm and decoration rendering of music can touch people's heart and remove obstacles between people. It can help people open their hearts in enjoying the music together, which eventually leads to resonance.

Every civilized person is a social being. Any person cannot be isolated from the community. The main features of difference between human and animal world is that man is a part of the society. Confucius said:'It is impossible to associate with birds and beasts, as if they were the same with us. If I cannot associate with people, then what shall I associate with?" (Chapter of Wei Tsze in Confucian Analects) He denounced those hermits who only consider their own moral perfection and abandon the social responsibility, and regarded them as "birds and beasts". Without this social feature, we are no more than beasts. It shows that Confucius's denial of the hermit and the recognition of social responsibility, which opened the first step to identify the social character of people in ancient China. Xun $\mathrm{Zi}$ also said that the water and fire have smell without life, the plants have breath without consciousness, animals have consciousness without morality and justice, and people have life, breath, consciousness, morality and justice as well, so man is the noblest in the world, ...because man is the social being. (Chapter of Wang Zhi) Therefore, if a person lives in the world without interacting with others, he looks like standing against the wall alone. Then we may say that he is the same with the beasts. The wonderful sounds of the instrument can attract people to gather together. It fully demonstrates the social function of the music. In the atmosphere of music, people get together to sing, on the one hand is to exchange the music skills; on the other hand is to communicate feelings. People and music achieve harmony and unity, at the same time, people's souls achieve a harmonious unity, which makes the individual and the whole social groups a harmonious unity. So Confucius was accompanied by music all his life and made friends with music, following the rhythm of others to learn music. Gentlemen thorough understanding music have mutual affinity, mutual adoration, and attract each other, they set up a bridge of benevolence between people in enjoying the harmonious music. So the music and 
Ren (benevolence) share the same openness, and music can arouse the benevolence in the heart and make man to be the social being.

\section{The Political Function of Music Education in Changing the Customs}

Confucius said in the chapter Yong Ye of Confucian Analects that Ran Qiu is a man of various abilities, so what is the difficulty for him in political management? From one aspect, it reflected Confucius's ritual view that music and politics were interlinked. 'The emperors in ancient times attached great importance to the way of music education, because the music could root deeply in people's mind and educate people quickly. (Yue Lun of Xun Zi) So the ruling class always concerned about music education. Yan Yuan of Confucian Analects records that Ji Kangzi asked Confucius about government. Confucius replied, "to govern is to rectify. If you lead the people by being rectified yourself, who will dare not be rectified." So government is leading people, which should follow the right path. Otherwise, people in different classes will smash and grind against each other, and human relations will be destroyed. It is the so-called the Falling of Ceremony and Propriety of the Spring and Autumn Period. Therefore, to rectify music is one of the main contents of the politics. The upper class like Ya music, the common people will follow. "Then to gather people by way of benevolence and ensure the stability of people's lives by music education." (The chapter Li Yun of the Book Li Ji) The music education was one of the a supplementary means in running the country because it can change people's temperament. Music education is moral education, and the cultivation of morality and personality serves as the ultimate goal of music education. So, the music is an invisible means of social control in governing. The people's heart can be rectified and the whole world will tend to practice Ren (benevolence).

In ancient China, the poems need to be sung, and accompanied by musical instruments. And putting them together can be called music. In the Spring and Autumn period, the music was mostly based on the "Book of Odes", which had a broad social significance and made the ancient Ya music a profound cultural connotation. Confucius said, "The Odes can stimulate your emotion, enlarge your fellowship, and express your grievances. They help you in your immediate service to your parents and in your more remote service to your rulers. They widen your acquaintance with the names of birds, beasts, and plants. (chapter Yang Huo of Confucian Analects) The subject can express their will by studying and singing poems, which can satirize reality, attract people live together in harmony. Therefore, the prevalence of music education had the direct contact with the patriarchal system in feudalistic society and the ethics morals of the respect for seniority. The king could know different customs, his wrongdoing by listening to the music from different regions, then he examine himself and make corrections. The lyrics were the poems in ancient China, and the rulers transmitted their strategy of governing to people of the country by the spread of the poems. Confucius revised the Book of Songs, and the rulers adopted it to carry out their education. Then the education mode or ruling pattern was that from singing the lyrics to music education, to virtue cultivation, and to political education. There is clear moral connotation in music, and the virtue can be cultivated by music education for the syraesthesia and moral empathy. So it is obvious to use music to carry out politics.

In addition, the political function of music education is also reflected in the harmonious society directed by music. In the idea of the ancients, harmony means unity and peace. Xun $\mathrm{Zi}$ 
also said "to make the music harmonious is to find a basic tone to determine it, and so does politics.'(Yue Lun of Xun Zi) The harmonious rhythm leads to harmonious music, by extension, gentle music leads to gentle temperament, harmonious music results in harmony between people and all walks of life. Therefore, peaceful and harmonious music has an important ethical function, and it is good way to regulate a family. Xun $\mathrm{Zi}$ pointed out that "When all the members of the family listen to the peaceful and harmonious music together, the kindly affections will be expanded in the family. When all people of a town listen to the peaceful and harmonious music together, the ethical morality of respect for seniority will be set up." (Yue Lun of Xun Zi). Then all people in a country will show mutual respect and love under the influence of the peaceful and harmonious music. In the harmonious society, it is easy to rule. "The mob dare not make insurrection, the dukes and princes submit, the weapons are put back in the arsenal, the criminal penalty is waived, people are no longer afraid, and the king is no longer angry. (Yue Shu of Shi Ji) So, music and politics are interlinked, and music education is an important and effective means to realize a harmonious society. In other words, the music has an important function in managing the country.

Throughout the history of the world, the songs written by the musicians of all countries are the aspirations of the people. Music can purify one's mind, cultivate people's sentiments, and make a deep effect on people's political ideas as well. Confucius once said that "there is no better way than the refined music in changing the customs.'(Guang Yaodao of Xiao Jing) The music can change the old customs, like the gentle wind and small rain, soundless and stirless. In short, the music education of Confucius is to make "all under heaven will return to humanity virtue to him.'(Yan Yuan of Confucian Analects) Therefore, focusing on social ethics becomes the essential feature of Confucius's music education.

\section{Conclusion}

In Confucius's eyes, the music should establish a connection with life. Otherwise, the music will be formal and empty, as people who really know music can understand the true meaning of life. Even today, Confucius's music education, attaching greater importance to the functional significance of the music, can be useful in dealing with the expansion of instrument rationality and "People's Being Digital ". So, if we lack the humanistic consciousness and the historical mission of inheriting the traditional culture, then to carry forward the excellence of the traditional music culture will become empty talk.

\section{Acknowledgement}

This research was financially supported by the National social sciences planning project (2012 CZX032).

\section{References}

[1] Zhe-hou Li. Three Major Work of Aesthetic Theory, An Hui Literature and Art Publishing House, (22)1994

[2] Lian-kang Ji. Qin Cao, People’s Music Publishing House, (49)1990

[3] Mu Qian. New Annotations of the Analects of Confucius, (56)2003 